\title{
Testicular Cancer pM1 TNM Finding v8
}

National Cancer Institute

\section{Source}

National Cancer Institute. Testicular Cancer pM1 TNM Finding v8. NCI Thesaurus. Code C140206.

Testicular cancer with distant metastasis. (from AJCC 8th Ed.) 